\title{
Establishment of White Pine Blister Rust in New Mexico
}

Brian W. Geils

Additional index words. Cronarti um ribicola, introduction, $R$ ibes

W

hite pine blister rust (WPBR) (C ronartium ribicola Fischer) is a recently established pathogen of southwestern white pine (Pinus strobiformis

Engelm.) and R ibes L. (currants and gooseberries) in $\mathrm{N}$ ew M exico ( $H$ awksworth, 1990). Based on the apparent age of the oldest canker found, the outbreak began about 1970 on the western escarpment of the Sacramento M ountains, O tero County (Geils et al., 1999). By 1999, the rust was found in several additional areas in N ew M exico and on 62\%(111 of 180) of plots distributed across the range of white pine in the Sacramento M ountains (G eils et al., 1999).

Several hypotheses propose to explain the spread of WPBR from infested areas in Wyoming, California, and Idaho, 900 to $1500 \mathrm{~km}$ (600 to 900 miles) to the north and northwest. Van Arsdel et al. (1998) argue that introduction by longdistance, aerial transport of aeciospores from pine to $\mathrm{R}$ ibes is more plausible than by transplanted, infected stock (either pine or R ibes). They cite how other rusts are observed to spread similar long distances. They also relate that the oldest rust cankers in the Sacramento M ountains predate the first recorded planting of white pine seedlings from I daho and that the oldest cankers are far from the nearest home sites (where infected $R$ ibes may have been planted). A study of the population genetics of WPBR conducted by R.C. H amlin (personal communication) suggests the outbreak in the Sacramento M ountains resulted from a single introduction of inoculum from somewhere in western $\mathrm{N}$ orth America. $\mathrm{H}$ is study found the rust in the Sacramento M ountains to have low genetic diversity (founder effect) and greater genetic similarity to other western populations than to eastern populations. Preliminary examination of regional air flow patterns into Arizona and $\mathrm{N}$ ew $\mathrm{M}$ exico during the late spring suggests the origin of the rust was the southern Sierra N evada where the rust has been established since the 1960s. The dispersal capacity of the rust in the southwestern $U$ nited States is demonstrated by its spread throughout the Sacramento and adjacent White M ountains, into the Capitan M ountains, across a gap in host distribution of $50 \mathrm{~km}$ (30 miles), and to Gallinas Peak, a gap of $90 \mathrm{~km}$ (50 miles). Additional populations of southwestern white pine are located to the west in the Gila M ountains and to the northwest in the M agdalina and San M ateo M ountains (Little, 1971).

Research Plant Pathologist, U SD A Forest Service, Rocky M ountain Research Station, Southwest Forest Science Complex, 2500 South Pine Knoll D rive, Flagstaff, AZ 86001.

The cost of publishing this paper was defrayed in part by the payment of page charges. U nder postal regulations, this paper therefore must be hereby marked advertisement solely to indicate this fact. 
Geils et al. (1999) established a series of vegetation plots and meteorology stations at randomly selected sites in six areas across the Sacramento M ountains to determine rust history, distribution, incidence, severity, and relationship to $R$ ibes. The first summaries of that survey indicate that following initial establishment of the rust, infection of pines occurred frequently after 1983 and spread therust throughout the range of the host. The rust appears to have become common in the northwest portion of the forest by 1985 and elsewhere several years later. O nce established locally, intensification occurred in most years. M eteorological summaries confirm that favorable conditions for infection of pines prevailed across the forest at least several times during 1998 and 1999. The most obvious trend was for greater rust infestation, incidence, and severity at elevations above $2400 \mathrm{~m}(8000$ $\mathrm{ft}$ ). 0 ver $85 \%$ (97 of 113 ) of thehigher elevation plots were infested; whereas only $22 \%$ (14 of 63 ) of the lower elevation plotswereinfested. $0 \mathrm{n}$ higher elevation, infested plots $55 \%$ of the white pine were infected with an average of 2.5 cankers per tree; on lower elevation, infested plots only $32 \%$ of white pineswereinfected with an average 0.9 cankers per tree. These results are consistent with findings reported by V an Arsdel et al. (1998). Girdling stem cankerswere generally and quickly lethal on small trees and the cause of topkill to larger trees (leading to reduction of growth, survival, and reproduction). $\mathrm{R}$ ibes were found to occur mostly at higher elevations in patches of varioussizes(several to hundreds of meters of live stem per bush). Although white pines and $R$ ibes were sometimesfound within meters of each other, the density of $\mathrm{R}$ ibes (in terms of meters of live stem per hectare) was low and extremely variable. Additional plots and analyses are required before more quantitative relationships can be described.
White pine blister rust is a special threat in the southwestern U nited States because white pines are generally isolated into small populationsand therefore subject to local extinction. When infested these scattered populations could provide a bridge for rust migration into northern M exico or the southern R ocky M ountains. Potential impacts from the loss of the white pine include many adverse effects on ecological processes and biodiversity. Further spread of the rust may behastened by landscape planting of currants, gooseberries, and white pines in forest-urban areas. Research is underway on WPBR epidemiology and $R$ ibes ecology to provide for better evaluations of rust hazard and impact and recommendations for control. For example, the orange gooseberry ( $R$. pinetorum $G$ reene) appears to support a greater production of rust spores capable of infecting pines than many other Ribes species native to $\mathrm{N}$ ew $M$ exico. Cultivation of thisspeciesmay therefore be discouraged to protect white pines.

\section{Literature cited}

Geils, B.W., D.A. Conklin, and E.P. Van Arsdel. 1999. A preliminary hazard model of white pineblister rust for theSacramento Ranger District, Lincoln National Forest. U SD A For. Serv. Rocky M t. Res. Sta. (Fort Collins, Colo.) Res. N ote RM RS-RN -6.

H awksworth, F.G. 1990. White pine blister rust in $\mathrm{N}$ ew M exico. Plant $\mathrm{D}$ is. 74:938.

Little, Jr., D.L. 1971. Atlas of U nited Statestrees. vol. 1. Conifers and important hardwoods. U SD A For. Serv. M ap 72-W. $\mathrm{M}$ isc. Publ. 1146.

Van Arsdel, E.P., D.A. Conklin, J .B. Popp, and B.W. Geils. 1998. The distribution of white pine blister rust in the Sacramento M ountains of N ew M exico, p. 275-283. In: R. Jalkanen, P.E. Crane, J.A. Walla, and T. Aalto (eds.). Proc, 1st Intl. U nion of For. Res. Org., Rusts of Forest Trees Working Party C onf., 2-7 Aug., Saariselka, Finland. Res. Pap. 712. Finnish For. Res. Inst., Rovaniemi. 